Journal of Telenursing (JOTING)

Volume 1, Nomor 2, Desember 2019

e-ISSN: 2684-8988

p-ISSN: 2684-8996

DOI: https://doi.org/10.31539/joting.v1i2.932

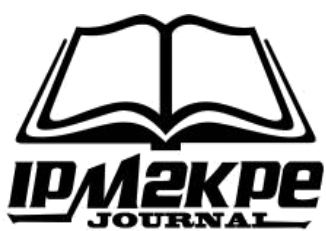

\title{
ORIENTASI PERAWAT BARU DI RUMAH SAKIT DENGAN SISTEM E-LEARNING
}

\author{
Rita setianingrum ${ }^{1}$, Santi Farida Rachmi ${ }^{2}$ \\ Universitas Indonesia ${ }^{1,2}$ \\ ritasetyaningrum9760@gmail.com ${ }^{1}$
}

\begin{abstract}
ABSTRAK
Tujuan penelitian ini adalah untuk menjelaskan manfaat aplikasi sistem $e$ - learning terhadap perawat baru di Rumah Sakit. Desain penelitian yang digunakan dalam penelitian ini menggunakan metode literature review. Hasil penelitian usia muda yaitu 22-25 tahun paling banyak menggunakan E-learning dengan persentase sebesar 45.16\%. Simpulan, pelaksanaan orientasi perawat baru dengan metode E-learning dapat memberikan hasil yang efektif. E-learning memberikan berbagai manfaat positif kepada perawat baru dalam menghadapi persiapan kerja di lahan praktik. E-learning tidak hanya memberikan bekal secara teori, namun juga memberikan dukungan psikologis karena dapat menurunkan tingkat kecemasan yang dihadapi oleh perawat baru.
\end{abstract}

Kata Kunci: Elektronik, Orientasi, Pembelajaran, Perawat Baru

\begin{abstract}
The purpose of this study is to explain the benefits of the application of e-learning systems to new nurses in hospitals. The research design used in this study uses the literature review method. The results of young research that is 22-25 years most use Elearning with a percentage of $45.16 \%$. Conclusions, implementation of the orientation of new nurses with the E-learning method can provide effective results. E-learning provides a variety of positive benefits for new nurses in facing work preparation in the practice field. E-learning not only provides a theoretical provision, but also provides psychological support because it can reduce the level of anxiety faced by new nurses.
\end{abstract}

Keywords: Electronics, Orientation, Learning, New Nurse 


\section{PENDAHULUAN}

Perawat adalah salah satu petugas kesehatan yang memiliki peranan penting dalam pelayanan kesehatan baik di komunitas maupun rumah sakit. Peranan penting tersebut mengharuskan perawat memiliki kualitas yang baik dalam bekerja. Kualitas yang mencakup teori maupun praktik keperawatan. Kualitas tersebut akan berpengaruh besar terhadap pelayanan yang diberikan oleh perawat. Perawat merupakan sumber daya manusia yang sangat penting dalam menjalankan proses organisasi termasuk di dalamnya rumah sakit untuk mencapai tujuan yang sama (Wijaya et al., 2018).

Berdasarkan Badan Pengembangan dan Pemberdayaan Sumber Daya Manusia Kesehatan (dalam Infodatin, 2017) terdapat 1.000 .780 orang yang didayagunakan dalam pelayanan kesehatan di seluruh Indonesia. Terdapat enam besar tenaga kesehatan yang meliputi dokter umum, dokter spesialis, dokter gigi, bidan, perawat dan tenaga farmasi yang berjumlah 601.228 orang (BPPSDMK dalam Infodatin, 2017). Dari keenam kategori tenaga kesehatan tersebut, jumlah perawat menempati posisi pertama dalam pelayanan kesehatan. Jumlah tenaga keperawatan mencapai 49\% (296.876 orang). Sebagian besar perawat bekerja di rumah sakit dengan presentase $58.26 \%$ dari 9756 Unit Puskemas dan 144 Unit rumah sakit (SDMK dalam Infodatin).

Jumlah tenaga perawat yang menempati posisi pertama dalam pelayanan kesehatan tidak berbanding lurus dengan banyaknya jumlah penduduk tiap tahunnya. Berdasarkan data jumlah perawat yang bekerja tiap tahunnya cenderung menurun. Hal tersebut belum memenuhi target rasio perawat yang ditetapkan oleh Rencana Strategis Kementerian Kesehatan 2015-2019 yaitu 180 perawat per 100.000 penduduk. Pada tahun 2014 tercatat 94.07 perawat per 100.000 penduduk. Rasio tersebut menurun di tahun 2015 menjadi 87.65 perawat per 100.000 penduduk (Infodantin, 2017).

Rumah sakit dalam peningkatan mutu sumber daya manusia dapat dilakukan dengan berbagai cara seperti pelatihan, case study dan berbagai program, salah satunya adalah orientasi. Program staff development perawat adalah program yang komprehensif yang termasuk didalamnya orientasi staf perawat baru, in-service education atau pelatihan internal, program pendidikan berkelanjutan (continuing education program) dan job-related counseling. Pelatihan internal adalah suatu program pelatihan singkat yang diberikan oleh institusi bagi stafnya. Program dilaksanakan di institusi yang bertujuan untuk meningkatkan ketrampilan dan pengetahuan pada suatu area yang spesifik. Orientasi dapat diberikan kepada perawat-perawat baru yang akan bergabung dalam pelayanan di rumah sakit agar siap untuk bekerja. Orientasi merupakan hal yang penting bagi seorang perawat baru. Hal ini, akan membantu perawat untuk memperoleh informasi baru terkait lingkungan kerja hingga proses bekerja di rumah sakit. Orientasi yang diberikan dapat berupa konvensional maupun non-konvensional. Metode non-konvensional salah satunya berupa orientasi menggunakan e-learning (Prasetyanto, 2019).

E-learning adalah suatu pembelajaran yang berbasis teknologi informasi. Hal ini akan memudahkan perawat baru untuk menerima orientasi dengan mudah. E-learning sangat membantu perawat untuk mendapatkan informasi sewaktu-waktu. Perawat akan dengan mudah dapat mengakses dan mendapatkan informasi pada saat dibutuhkan. Sebuah rumah sakit atau instansi pendidikan dapat melakukannya dengan mengaplikasikan sistem e-learning secara komprehensif yang dengan mudah dapat mereferensi informasi yang dibutuhkan. e-learning dapat dengan mudah di akses oleh setiap perawat dari lokasi manapunn dan dimana berada dengan adanya koneksi internet. Pembelajaran tradisional di ruang kelas biasanya dilakukan selama 2 jam akan 
tetapi dengan program e-learning perawat dapat membatasinya dengan memilih topik yang penting sehingga akan lebih mudah bagi perawat untuk mengakses. E-learning memberikan tutorial bagi perawat sehingga perawat merasa memiliki pengajar pribadi.

Matthew Comerchero dalam E-Learning, Concepts and Techniques Bloomsburg, (2006) mendefinisikan: E-learning adalah sarana pendidikan yang mencakup motivasi diri sendiri, komunikasi, efisiensi, dan teknologi. Karena ada keterbatasan dalam interaksi sosial, siswa harus menjaga diri mereka tetap termotivasi. E-learning efisien karena mengeliminasi jarak dan arus pulang-pergi.Jarak dieliminasi karena isi dari elearning didesain dengan media yang dapat diakses dariterminal komputer yang memiliki peralatan yang sesuai dan sarana teknologi lainnya yang dapatmengakses jaringan atau Internet. Dari definisi-definisi yang muncul dapat kita simpulkan bahwa sistem atau konsep pendidikan yang memanfaatkan teknologi informasi dalam proses belajar mengajar dapat disebut sebagai suatu e-Learning (Wahono, 2005).

Prakteknya e-learning memerlukan bantuan teknologi. Karena itu dikenal istilah: Computer Based Learning (CBL) yaitu pembelajaran yang sepenuhnya menggunakan komputer; Computer Assisted Learning (CAL) yaitu pembelajaran yang menggunakan alat bantu utama komputer. Teknologi pembelajaran terus berkembang. Namun pada prinsipnya teknologi tersebut dapat dikelompokkan menjadi dua, yaitu: a. Technology based learning, b. Technology based web-learning. technology based learning ini pada prinsipnya terdiri dari audio information technologies (radio, audio tape, voice mail telephone) dan video information technologies (video tape, video text, video messaging). Sedangkan technology Based web-learning pada dasarnya adalah data information technologies (bulletin board, Internet, e-mail, tele-collaboration). Dalam pelaksanaan pembelajaran sehari-hari, yang sering dijumpai adalah kombinasi dari teknologi yang dituliskan di atas (audio/data, video/data, audio/video). Teknologi ini juga sering di pakai pada pendidikan jarak jauh (distance education), dimasudkan agar komunikasi antara murid dan guru bisa terjadi dengan keunggulan teknologi e-learning ini.

Hal ini didukung oleh penelitian yang dilakukan oleh Suratmi \& Suwardi (2017) yang menyatakan bahwa e-learning berbasis web efektif dalam meningkatkan kompetensi perawat di RS Muhammadiyah Lamongan. Hal senada juga disampaikan Driscoll (2017) di Amerika, bahwa pembelajaran dengan simulasi menggunakan $e$ learning merupakan pendekatan yang efektif terhadap masalah praktik yang sering dihadapi perawat baru dalam melihat tanda-tanda keadaan kritis pasien. Simulasi menggunakan teknologi dapat membantu perawat baru meningkatkan kepercayaan diri dan pengalaman merawat pasien dalam keadaan kritis tanpa membahayakan pasien. Sementara keterbatasan penggunaan edukasi konvensional antara lain pelajaran berjalan membosankan, siswa menjadi pasif dan hanya menulis saja, karena pasif maka pengetahuan yang diperoleh mudah dilupakan, siswa hanya belajar menghafal tanpa pemahaman. Oleh karena itu, peneliti tertarik melakukan penelitian dengan metode kajian literature atau literature review yang bertujuan untuk mengetahui keefektifan orientasi perawat baru dengan sistem e-learning. 


\section{METODE PENELITIAN}

Strategi pencarian penelitian ini menggunakan metode literature review. Literature review merupakan penelitian secara komprehensif dengan melakukan interpretasi terhadap literatur yang berkaitan dengan topik tertentu artikel penelitian kuantitatif menjadi sumber data yang digunakan oleh peneliti.

Peneliti juga menggunakan kriteria inklusi dan eksklusi untuk mendapatkan artikel yang sesuai. Kriteria inklusi berupa artikel dalam bahasa Indonesia dan Inggris, artikel dengan bacaan free full text. Sedangkan, kriteria eksklusi berupa artikel berbayar dan hanya abstrak. Literatur dibatasi dengan kriteria: 2015-2019.

Peneliti menggunakan artikel-artikel yang berasal dari database akademik. Penggunaan database akademik membantu peneliti untuk mencari informasi yang terpercaya dan sesuai dengan penelitian. Database yang digunakan yaitu Pubmed, Google Scholar, Pro Quest, Science Direct, EBSCOhost, Scopus.

Dalam pencarian data, peneliti menggunakan keywords spesifik pada database tersebut. Peneliti menggunakan Boolean dalam menggabungkan keywords, frase atau sinonim berupa "AND" atau "OR". Keywords yang digunakan adalah graduate nurse", "orientation", "E-learning". Peneliti dapat melakukan penambahan atau pengurangan keywords jika tidak ditemukan artikel yang sesuai. Pendekatan analisa data yang dilakukan penelitian adalah pendekatan simplified approach. Pendekatan ini bertujuan untuk menggabungkan temuan beberapa penelitian dengan metode yang berbeda.

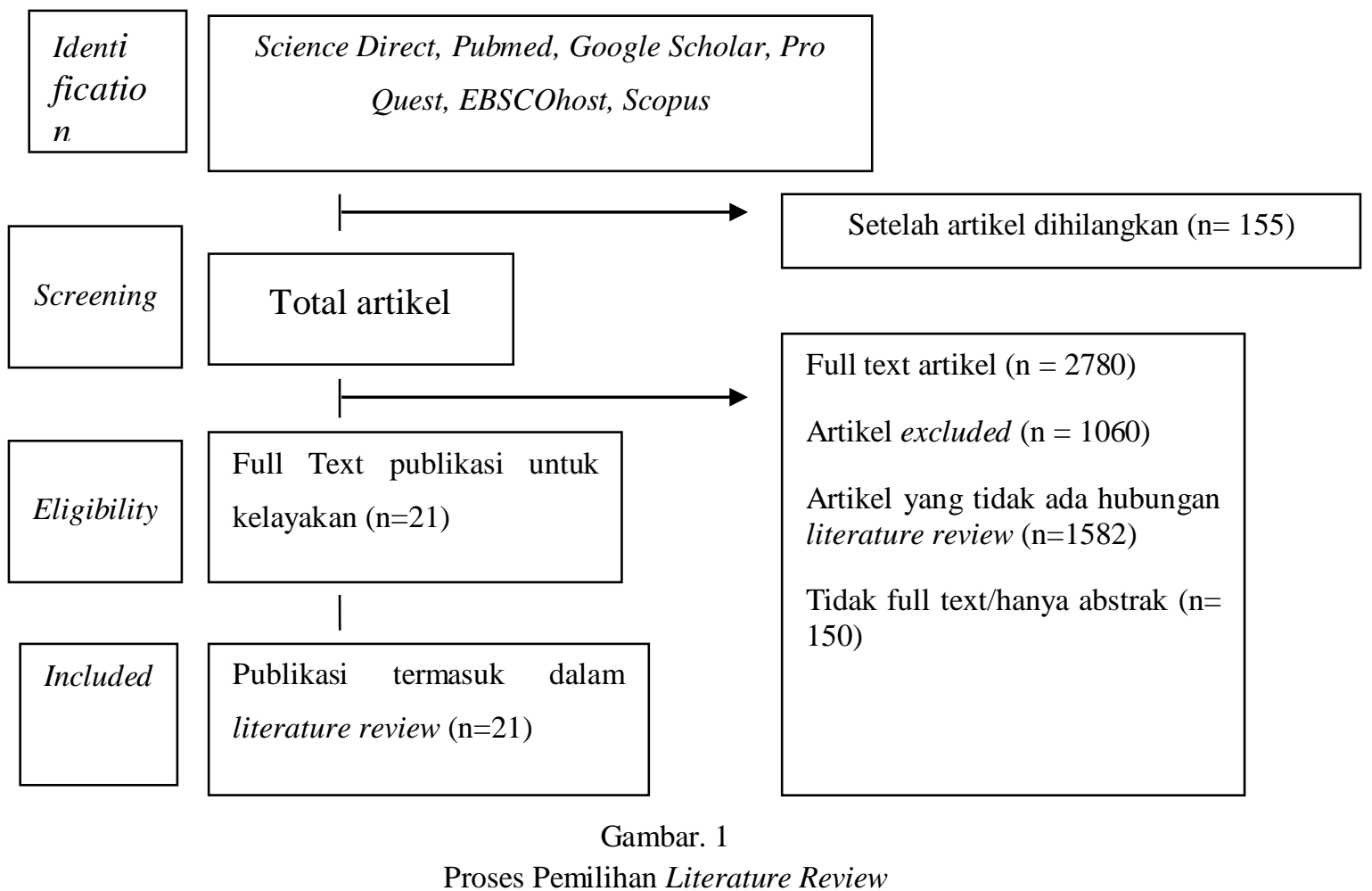




\section{HASIL PENELITIAN}

Tabel. 1

Faktor yang Mempengaruhi Perawat

terhadap Penerimaan E-Learning

\begin{tabular}{|c|c|c|c|}
\hline $\begin{array}{l}\text { Kelompok } \\
\text { E-learrning }\end{array}$ & $\begin{array}{l}\text { Usia } \\
\text { Muda } \\
22-25\end{array}$ & P Value & $\Delta$ \\
\hline Perempuan & $45-16 \%$ & 0,001 & 5,78 \\
\hline Laki-Laki & $68 \%$ & 0,001 & 7,33 \\
\hline
\end{tabular}

Berdasarkan tabel 1 Pembelajaran dengan E-learning merupakan salah satu metode pembelajaran yang dianggap efektif. Ada beberapa faktor yang mempengaruhi perawat dalam penerimaan e-learning. pertama, usia sangat berpengaruh terhadap penerimaan perawatan metode e-learning. Usia muda yaitu 22-25 tahun paling banyak menggunakan e-learning dengan presentase sebesar $45-16 \%$, jenis kelamin wanita mengikuti sarana program e-learning dibandingkan jenis kelamin pria sebesar $68 \%$.

\section{PEMBAHASAN}

Perawat merupakan ujung tombak dari pelayanan kesehatan di rumah sakit. Rasio jumlah perawat dengan jumlah penduduk yang belum sesuai dengan target yang ada dapat mempengaruhi kinerja dari perawat. Oleh karena itu, perawat harus memiliki kualitas yang baik dalam bekerja terlebih dengan adanya perawat-perawat baru di berbagai area. Perawat baru dengan berbagai karakteristik dan latar belakang memiliki banyak kecemasan yang dihadapi mengenai persiapan praktik keperawatan, ketidaksiapan secara teori ataupun psikologis dalam melakukan pelayanan ataupun penempatan kerja yang tidak diharapkan (Rush et al., 2018). Pelayanan asuhan keperawatan yang berkualitas dan profesional merupakan target yang ingin dicapai untuk meningkatkan mutu pada Rumah Sakit (Mangkunegara, 2007).

Kualitas atau mutu sebuah pelayanan kesehatan di rumah sakit dapat dilihat dari sudut pandang petugas kesehatan, untuk meningkatkan derajat kesehatan pasien dan masyarakat harus memberikan pelayanan kesehatan yang tepat. Pelayanan keperawatan adalah bagian dari sistem pelayanan kesehatan di Rumah Sakit yang mempunyai fungsi menjaga mutu pelayanan, sering dijadikan barometer oleh masyarakat dalam menilai mutu rumah sakit, sehingga menuntut adanya profesionalisme perawat dalam bekerja yang ditunjukkan oleh hasil kinerja perawat, baik itu perawat pelaksana maupun pengelola dalam memberikan asuhan keperawatan kepada klien. Pelaksanaan kerja perawat yang maksimal dalam pelayanan kesehatan yang berkualitas terjadi bila sistem pelaksanaan asuhan keperawatan yang dilakukan mendukung praktik keperawatan profesional sesuai standar (Budiawan, 2015).

Orientasi merupakan hal yang penting bagi seorang perawat baru. Hal ini, akan membantu perawat untuk memperoleh informasi baru terkait. Lingkungan kerja hingga proses bekerja di rumah sakit. Orientasi yang diberikan dapat berupa konvensional maupun non-konvensional. Metode non-konvensional salah satunya berupa orientasi menggunakan e-learning.

Dukungan tersebut dapat diberikan dengan berbagai macam metode baik dengan mentorship, pembelajaran tatap muka secara langsung, dan orientasi menggunakan $E$ learning (Matthias et al., 2019; Rush et al., 2018). Pada masa kini, era digital telah banyak memasuki berbagai aspek kehidupan manusia. E-learning merupakan suatu 
sistem atau konsep pendidikan yang memanfaatkan teknologi informasi dalam proses belajar mengajar dengan meniadakan tatap muka secara langsung (Michael dalam Sianturi \& Lisum, 2018). Sehingga, kecemasan atau ketakutan yang dihadapi perawat baru akan berkurang. Selain itu, bahan pembelajaran dalam E-learning akan membuat pelajar siap dalam melakukan suatu diskusi dan siap dalam melakukan praktik keperawatan nantinya Penggunaan teknologi ataupun E-learning akan membantu perawat dalam meningkatkan pelayanan kepada pasien dan mengetahui sistem kerja dan visi di rumah sakit (Syafrandinel, 2019 Hermansyah \& Munazar, 2017).

E-learning memiliki banyak manfaat dalam penggunaannya. Pertama, E-learning bertujuan untuk meningkatkan kompetensi perawat, pengetahuan perawat serta kepercayaan diri di bidang keperawatan (Syafrandinel, 2019; Weeks, et al., 2019; Driscoll, 2017; Elkman, 2018). Kedua, E-learning dapat meningkatkan motivasi belajar bagi perawat dengan adanya fitur-fitur program yang lebih menarik dan aktif, serta memberikan gambaran awal kepada perawat baru mengenai praktik keperawatan (Syafrandinel, 2019). Ketiga, dengan berbagai karakteristik dan latar belakang dari perawat. E-learning dapat menjadi sumber acuan yang sama dalam praktik keperawatan (Syafrandinel, 2019). Keempat, e-learning merupakan alternative pembelajaran yang bersifat flexible dan efektif (Elkman, 2018; Sianturi \& Lisum; 2018). Kelima, $e$ learning dengan berbagai fitur yang ada membuat perawat baru mampu untuk mengintegrasikan serta memahami teori dan latihan, serta membuat keputusan klinis yang tidak berisiko terhadap pasien (Prasetyanto \& Sukihananto, 2019; Weeks et al., 2019; Driscoll, 2017).

Penggunaan e-learning sebagai metode orientasi perawat baru menunjukkan evaluasi yang baik. Penggunaan e-learning dapat meningkatkan motivasi pengguna dan tingkat keyakinan pemakainya (Sianturi \& Lisum, 2018). Suratmi \& Suwardi (2017) menyatakan bahwa kompetensi perawat pasca penggunaan E-learning di RS Muhammadiyah Lamongan meningkat dengan nilai rata-rata 79.8 dalam kategori baik.

Salah satu kesalahan berpikir tentang e-learning adalah e-learning hanya menciptakan sistem belajar secara formal, seperti dalam bentuk kursus. Namun faktanya adalah saat ini $80 \%$ pembelajaran didapat secara informal. Banyak orang saat beraktivitas sehari - hari dan menghadapi suatu masalah membutuhkan solusi secepatnya. Kesalahan lainnya dalam berpikir tentang e-learning bahwa e-learning hanya membuat kontensaja, sebenarnya e-learning adalah sebuah aktivitas sosial. Elearning menyediakan pengalaman belajar yang kuat melalui komunitas online pengguna e-learning. Karena manusia adalah makhluk sosial, jadi ada banyak kesempatan untuk berkomunikasi, berkolaborasi, dan berbagi ilmu antara sesama pengguna e-learning (Gatewood, 2019).

Kualitas penyelenggaraan pembelajaran e-learning ini tidak diperngaruhi oleh waktu paparan mahasiswa terhadap internet, konten yang diberikan pada saat pembelajaran e-learning dan fasilitas yang digunakan oleh mahasiswa seperti komputer dan internet yang dapat menunjang mahasiswa melakukan e-learning. Hal ini disesuaikan dengan gaya belajar mahasiswa pada generasi milenial, sehingga proses pembelajaran menjadi lebih dinamis. Mahasiswa dapat terdorong untuk selalu belajar dan selalu mencari tahu tentang kesehatan. Dengan begitu motivasi mahasiswa untuk belajar menjadi lebih tinggi dan pada akhirnya akan mempengaruhi prestasi belajar mahasiswa. Dosen sebagai fasilitator bertanggung jawab untuk memfasilitasi gaya belajar dengan menggunakan metode pembelajaran yang sesuai. Dengan demikian proses belajar mengajar menjadi lebih efektif (Sianturi \& Lisum, 2018). 
Secara ringkas e-learning perlu diciptakan seolah-olah peserta didik belajar secara konvensional, hanya saja dipindahkan kedalam sistem digital melalui internet. Karena itu e-learning perlu mengadaptasi unsur-unsur yang biasa dilakukan dalam sistem pembelajaran konvensional. Misalnya dimulai dari perumusan tujuan operasional dan dapat diukur, ada apersepsi atau pre test, membangkitkan motivasi, menggunakan bahasa yang komunikatif, uraian materi yang jelas, contoh-contoh konkrit, problem solving, tanya jawab, diskusi, post test, sampai penugasan dan kegiatan tindak lanjutnya. Oleh karena itu merancang e-learning perlu melibatkan pihak terkait, antara lain: pengajar, ahli materi, ahli komunikasi, programmer, seniman, dan lain-lain (Hermansyah \& Munazar, 2017).

Modul online learning yang interaktif untuk pelatihan internal merupakan strategi yang efektif untuk menurunkan kesalahan pada perawat di dalam memberikan Asuhan Keperawatan dilayanan kesehatan. Banyaknya hasil penelitian yang menemukan bahwa pengetahuan perawat terkait dengan diabetes dapat ditingkatkan dengan memberikan metode pendidikan tambahan tentang Asuhan Keperawatan yang tepat dan aman pada pasien diabetes. Program e-learning diberikan kepada perawat dikemas dalam bentuk yang interaktif yaitu active learning, problem solving, dan juga adanya feedback langsung dari perawat yang mengikuti program tersebut. Program e-learning sangat membantu di dalam memberikan pendidikan terkait dengan implementasi yang tepat di dalam memberikan Asuhan Keperawatan dilayanan kesehatan, dimana program pendidikan dapat diberikan kepada perawat dalam jumlah yang besar (Astner \& Suffoletto 2018).

Pembahasan studi literatur penerapan e-learning di pendidikan keperawatan, pemanfaatan teknologi tersebut mempunyai dampak yang berseberangan ketika digunakan secara baik maka dampaknya akan positif tapi sebaliknya jika digunakan untuk hal yang buruk maka dampaknya pun akan buruk juga. Kelemahan dalam menggunakan e-learning adalah kreatifitas dari animator (virtual learning untuk menampilkan avatar yang baik dam memiliki karakter serta original dari animator), membutuhkan dukungan anggaran besar, fasilitas sarana dan prasarana yang memadai, dibutuhkan juga ahli teknologi informatika dan desain grafis yang mampu membuat web based and virtual. Selain dalam hal fasilitas diperlukan juga inovasi para tenaga pengajar meskipun memiliki keterbatasan dalam hal fasilitas pendukung (Elkman, 2018).

\section{Manfaat Orientasi E-Learning bagi Perawat Baru}

E-learning memiliki banyak manfaat dalam penggunaannya. Pertama, e-learning bertujuan untuk meningkatkan kompetensi perawat, pengetahuan perawat serta kepercayaan diri dibidang keperawata (Elkman, 2018). Kedua, e-learning dapat meningkatkan motivasi belajar bagi perawat dengan adanya fitur-fitur program yang lebih menarik dan aktif, serta memberikan gambaran awal kepada perawat baru mengenai praktik keperawatan (Syafrandinel, 2019). Ketiga, dengan berbagai karakteristik dan latar belakang dari perawat. E-learning dapat menjadi sumber acuan yang sama dalam praktik keperawatan (Syafrandinel, 2019). Keempat, e-learning merupakan alternatif pembelajaran yang bersifat flexible dan efektif (Elkman, 2018; Sianturi \& Lisum; 2018). Kelima, e-learning dengan berbagai fitur yang adamembuat perawat baru mampu untuk mengintegrasikan serta memahami teori dan latihan, serta membuat keputusan klinis yang tidak berisiko terhadap pasien persepsi perawat terhadap e-learning. 
Terdapat dua jurnal menyatakan e-learning ini dapat memperpendek waktu orientasi, perawat langsung bisa bekerja sehingga menjadikan pelayanan kesehatan meningkat. (Hasil belajar perawat dari metode E-learning mengalami peningkatkan dibandingkan tatap muka secara langsung (Elkman, 2018), termotivasi dengan metode belajar ini (Sianturi \& Lisum, 2018; Pitts \& Christenbery, 2019).

\section{SIMPULAN}

Pelaksanaan orientasi perawat baru dengan metode e-learning dapat memberikan hasil yang efektif. E-learning memberikan berbagai manfaat positif kepada perawat baru dalam menghadapi persiapan kerja di lahan praktik. E-learning tidak hanya memberikan bekal secara teori, namun juga memberikan dukungan psikologis karena dapat menurunkan tingkat kecemasan yang dihadapi oleh perawat baru. Pengembangan sistem e-learning juga diharapkan tidak hanya memperhitungkan masalah finansial dan profitabilitas, tetapi dapat dijadikan sebagai media strategis dan metode pembelajaran yang aktif, kreatif dan inovatif serta mampu mengimplementasikan dalam kehidupan sehari-hari dengan memperhatikan sisi psikologis peserta didik, mengakomodasi kepribadian dan cara belajar.

Program e-learning diberikan kepada perawat dikemas dalam bentuk yang interaktif yaitu active learning, problem solving, dan juga adanya feedback langsung dari perawat yang mengikuti program tersebut. Program e-learning sangat membantu di dalam memberikan pendidikan terkait dengan implementasi yang tepat di dalam memberikan asuhan keperawatan dilayanan kesehatan, dimana program pendidikan dapat diberikan kepada perawat dalam jumlah yang besar.

Kesuksesan dari e-learning juga dipengaruhi oleh kognitif dari e-learners, perilaku dan lingkungan. Oleh karena itu, diperlukannya pengembangan yang lebih terhadap pembuatan program e-learning sehingga dapat memicu keaktifan pengguna dan peningkatan keterampilan pengguna terhadap e-learning.

Harapan atas sistem e-learning di masa mendatang akan menjadi semakin efektif seiring dengan semakin berkembangnya teknologi dan metode pembelajaran yang digunakan. Pengembangan sistem e-learning juga diharapkan tidak hanya memperhitungkan masalah finansial dan profitabilitas saja, tetapi juga dapat dijadikan sebagai media strategis dan metode pembelajaran yang aktif, kreatif dan inovatif serta mampu mengimplementasikan dalam kehidupan sehari - hari dengan memperhatikan sisi psikologis peserta didik dan mengakomodasi berbagai kepribadian serta cara belajar.

\section{SARAN}

Metode pembelajaran dengan sistem e-learning khususnya untuk perawat baru sangat dianjurkan untuk mengurangi kecemasan atau ketakutan yang dihadapi serta siap diskusi dalam melakukan praktik keperawatan. Perlu menjadi pertimbangan bagi manajer keperawatan di Rumah Sakit untuk menetapkan program orientasi e-learning berbasis kompetensi sebagai standar operasional kerja dalam penerimaan perawat baru. Perlu adanya penelitian lebih lanjut untuk mengetahui pengaruh program orientasi berbasis kompetensi dengan kepuasan kerja perawat baru. 


\section{DAFTAR PUSTAKA}

Astner, J., \& Suffoletto, H. (2018). Emergency Department Crowding and Time at the Bedside: A Wearable Technology Feasibility Study. Journal of Emergency Nursing, 44(6), 624-631. doi:10.1016/j.jen.2018.03.005

Bloomsburg, B. (2006). E-Learning Concepts and Techniques. E Book. Institute for Interactive Technologies. USA: Bloomsburg University of Pennsylvania

Budiawan, I. N. (2015). Hubungan Kompetensi, Motivasi dan Beban Kerja Perawat Pelaksana dengan Kinerja Perawat di Ruang Rawat Inap Rumah Sakit Jiwa Propinsi Bali. Program Pascasarjana Universitas Udayana Denpasar

Driscoll, D. (2017). The New RN and Emergency Patient Care Scenarios: How Simulation Can Help. Open Access Library Journal, 5, 1-21. doi: 10.4236/oalib.1103904

Elkman, L. (2018). Developing and Evaluating an E-Learning Resource for Nurses in Haemato-Oncology. Cancer Nursing Practice, 17(6), 37-42. doi:10.7748/cnp.2018.e1510

Gatewood, E. (2019). Use of Simulation to Increase Self-Directed Learning for Nurse Practitioner Students. The Journal of nursing education, 58(2), 102-106. doi:10.3928/01484834-20190122

Hermansyah, H., \& Munazar, M. (2017). Persepsi E-Learning Berbasis Web pada Program Studi Keperawatan Banda Aceh Politeknik Kesehatan Kemenkes Aceh. Aceh Nutrition Journal, 2(1), 73-79

Infodatin. (2017). Pusat Data dan Informasi Kementerian Kesehatan Republik Indonesia: Situasi Tenaga Keperawatan Indonesia

Mangkunegara, A. A. P. (007). Manajemen Sumber Daya Manusia Perusahaan. Bandung: PT Remaja Rosdakarya

Matthias, A. D., Gazza, E. A., Triplet, S. (2019). Preparing Future Nurse Educators to Teach in the Environment. $J$ Nurse Educ, 58(8), 488-491. DOI: 10.3928/01484834-20190719-10

Pitts, C., Christenbery, T. (2019). Novice Nurse Practitioner Faculty and the Online Educator's Role. The Journal for Nurse Practitioners, 15(2), e29-e36

Prasetyanto, P., \& Sukihananto, S. (2019). Penerapan Sistem Informasi Keperawatan Virtually Nursing Technologies in Nursing Education: Sebuah Tinjauan Literatur, Jurnal Penelitian Kesehatan Suara Forikes

Rush, K. L., Janke, R., Duchscher, J. E., Philips, R., \& Kaur, S. (2018). Best Practices of Formal New Graduate Transition Programs: An Integrative Review. International Journal of Nursing Studies, 94, 139-158

Sianturi, S. R., \& Lisum, K. (2018). Peningkatan Motivasi Belajar melalui Evaluasi ELearning pada Institusi Keperawatan di Jakarta dan Depok. Jurnal Pendidikan Keperawatan Indonesia, 4(2), 122-130

Suratmi, S., \& Suwardi, S. (2017). Efektivitas E-learning Berbasis Web sebagai Pendukung In-House Training dalam Meningkatkan Kompetensi Perawat di Rumah Sakit Muhammadiyah Lamongan, Medical Technology and Public Health Journal, 1(2),109-117

Syafrandinel, R. (2019). Dampak Pemanfaatan Sistem E-learning pada Singapore General Hospital untuk Meningkatkan Kualitas SDM. Jakarta: Universitas Mercu Buana

Wahono, R. S. (2005). Pengantar E-Learning dan Pengembangannya. Portalwww.ilmukomputer.com. Indonesia 
Weeks, A., Weeks, K. W., Coben, D., O'Neill, D., Jones, A., Brown, M., \& Pontin, D. (2019). Developing and Integrating Nursing Competence Through Authentic Technology-Enhanced Clinical Simulation Education: Pedagogies for Reconceptualising the theory-practice gap. Nurse Education in Practice, 37, 2938. doi:10.1016/j.nepr.2019.04.01

Wijaya, D., Sitorus, R., \& Handiyani, H. (2012). Hubungan Program Orientasi Berbasis Kompetensi dengan Kinerja Perawat Baru. Jurnal Keperawatan Soedirman, $7(1), 10-16$ 